\title{
EquiLIBRIUM
}

Quarterly Journal of Economics and Economic Policy

2015 VOLUME 10 ISSUE 2, June

p-ISSN 1689-765X, e-ISSN 2353-3293

www.economic-policy.pl

Gorączkowska, J. (2015). Technological Parks and the Innovation Activity of Enterprises in the Industrial Networks - Developed vs. Intermediate Regions. Equilibrium. Quarterly Journal of Economics and Economic Policy, 10(2), pp. 137-156, DOI: http://dx.doi.org/10.12775/ EQUIL.2015.017

Jadwiga Gorączkowska*

University of Zielona Góra, Poland

\section{Technological Parks and the Innovation Activity of Enterprises in the Industrial Networks - Developed vs. Intermediate Regions}

JEL Classification: L60; O31; O32

Keywords: innovation; industry; technological parks; network

\begin{abstract}
Currently, technological parks constitute the most organisational and conceptually developed type of innovation centres and entrepreneurship. This results in the fact that they can be encountered in all highly developed countries in the world. They are also formed in the catching-up countries. However, one should consider whether the stimulation of innovation in the countries, which are not based on knowledge through institutional solutions used in the developed countries will turn out to be effective, because there is a technological gap between these countries. The aim of the article was therefore to determine, using the probit modelling, the direction and strength of technological parks on the innovation activity. The study covered two provinces: Silesian, which is one of the most developed regions in Poland and Pomeranian with the intermediate industrial system. The influence of technological parks on innovation was determined basing on the survey conducted in 1453 industrial enterprises. The main conclusions are brought down to the following theses: (1) using technological parks increases the chance for the implementation of new solutions by enterprises, (2) parks to a greater extent stimulate the innovation activity in the developed province, (3) enterprises
\end{abstract}

(C) Copyright Institute of Economic Research \& Polish Economic Society Branch in Toruń Date of submission: December 2, 2014; date of acceptance: May 16, 2015

* Contact: j.goraczkowska@wez.uz.zgora.pl, Wydział Ekonomii i Zarządzania Uniwersytetu Zielonogórskiego, ul. Podgórna 50, 65-246 Zielona Góra, Poland 
entering in the cross-regional network relations favours the selection of the technological park as the catalyst for innovation processes.

\section{Introduction}

In several recent years, the economic reality has provided a number of changes, of which the most serious one was the loss of importance of traditional production factors in favour of the advancing processes of globalisation and the computer and telecommunications revolution (Audretsch, 1998, p. 19). The changes associated with that can generate high costs for the economy. In this context the new role of state intervention appears, which should involve elimination or reduction of the costs of these transformations while supporting innovation (Balcerzak, 2009b, p. 75). The main task of the government is, therefore, to create institutional conditions, which will favour the high rate of productivity growth in the given country. It is a difficult task, because there are no ideal or model schemes for supporting innovation and entrepreneurship. Each solution should therefore be adapted to the conditions prevailing in the given country. Moreover, there is a risk that regulatory actions, instead of stimulating innovation and competitiveness, and thus contribute to building the economy based on knowledge, limit it. As the international studies prove, the mere availability of highly advanced technologies, relatively high quality of human capital and significantly aggregated investments in research and development do not constitute the guarantee of the economic use of new technological solutions. For this, we need incentives favouring the business diffusion of high technologies and new organisational solutions, the existence of which is closely related to the shape of the institutional system of each country (Balcerzak, 2009a, p. 741).

In modern economy it is recognised that technological parks, which belong to the group, constitute the most organisational and conceptually developed type of innovation and entrepreneurship centres (Mażewska \& Tórz, 2012, p. 25). The result is that when avoiding some differences related to their nomenclature and functioning, they can be found in all highly developed countries in the world.

The official definition by International Association of Science Parks (IASP) is: A Science Park is an organization managed by specialized professionals whose main aim is to increase the wealth of its community by promoting the culture of innovation and competitiveness of its associated businesses and knowledge based institutions. Parks should foster knowledge flows, mainly among park firms, as well as between these and external R\&D institutions (Jimenez-Moreno et al., 2013, p. 19). 
According to the Polish legislation, technological part is a group of separate buildings with the technical infrastructure, created in order to make the flow of knowledge and technology between scientific units (...) and entrepreneurs, on which the entrepreneurs using the modern technologies are offered with services within consulting in creation and development of companies, transfer of technologies and transformation of the results of scientific studies and developmental works into technological innovations, as well as creating these entrepreneurs the possibility to run the business activity by using the real estate and technical infrastructure on the contractual basis (Journal of Laws, 2002, art. 2, p. 15). This definition shows a wide range of specialised services offered to entrepreneurs conducting the business activity in the parks. Moreover, the need for transfer of knowledge from the science to the world of economy and transforming it into innovations indicates a high level of technological advancement of entities residing in the parks.

Technological parks often combine in one structure the functions of all other centres of innovations and entrepreneurship (Matusiak, 2009, p. 29). The fact of focusing in the given closed area of companies and business services evokes the "synergy effects", which combined with the R\&D activity and risk financing may become the innovation environment (Matusiak, 2004, p. 335). Improvement of the conditions for the course of the innovation processes is to lead to the increase of the competitiveness and boost of the regional development (Matusiak, 2008, p. 9). Here, what is important is the fact that the mere cooperation between companies is a necessary condition, but it may not be sufficient to begin the processes of knowledge transfer. For this reason, attention is also paid to the geographical concentration of economic entities, precisely through the creation of parks (Sarif \& Ismail, 2006, p. 134).

By acting in the network, the park residents have access to information, knowledge, ideas. It can be assumed that the network meets the functions of the incubator of the innovation process, in which the key role is played by communication, coordination and cooperation between participants. The role of the parks is to stimulate interactions between entities and institutions, while in the already developed parks the secondary meaning is found in the infrastructure, which is only a means to the end (Adamska \& Kotara, 2011, p. 76). It follows that in the process of managing innovations in the networks the biggest meaning is played by the provided services (BMWi, 2012, p. 6). Therefore, appropriate environment for the entrepreneurs should be created, which will allow the stimulation of the process of interaction and creativity (Kessler Park, 2014, p. 7). 
Technological parks in Poland are developing dynamically. In 1995 on our market there was one technological park. Currently, there are 40 identified parks and 14 park initiatives. Technological parks, however, are institutions, which were moved to the Polish ground from highly developed countries. The question which arises at this stage concerns the effectiveness of their impact in case of stimulating the innovation activity. Will they meet their functions in Poland, where in relation to the western countries there is a technological gap, and the processes of the transfer of knowledge from science to economy are not yet developed. Will the divergence in the impact of the parks in the case of the different level of development of the industrial system of the studied region be noticeable? How does the distance from the competitor, supplier and recipient and the relations of the companies with them influences the decision concerning the launch of the cooperation with technological parks? The aim of the paper is to determine the direction and strength of the influence of technological parks on the innovation activity of the regional industrial networks. The direction determines whether a park increases or reduces the chances for the occurrence of the innovation activity, and the strength clarifies the probability of the given phenomenon. In addition, it will also be possible to determine how the choice of cooperation with the parks is determined by the distances and relations along the supply chain and with a competitor. The research hypothesis is the statement that the innovation activity of companies will grow in industrial networks as a result of establishing cooperation with technological parks. Furthermore, also the divergence associated with a different level of development of the studied provinces will be noticeable.

In this paper, technological parks will be subjected to analysis from the point of view of companies, which used their services. Previous studies illustrating the functioning of technological parks were conducted in the parks. The approach to the issues from the point of view of the recipient of the park it is an interesting supplementation of these analyses.

\section{Methodology of the Research}

The selection of variables in the study of influence of technological parks on the innovation activity of companies is based on probability theory. This results from the dichotomous nature of the variables adopted for the study. Because the answers of the respondents were assigned with the value 1 , when they provided an affirmative answer, or 0 , when the answer was negative. 
In the first part of the study, these values were assigned to the following dependent variables, which were distinguished according to the international standards of the innovation activity measurement:

- Investment expenditures connected with the conduct of research and developmental works into new fixed assets, which included buildings, premises and lands, and the machines and technical equipment, as well as new computer software (Oslo, 2005, pp. 92-93)

$$
Y_{1 i}= \begin{cases}1, & \text { if the company incurred expenditures } \\ 0, & \text { if the company did not incur expenditures }\end{cases}
$$

- Implementations of new products and processes, both technological and those not directly related to production (Oslo, 2005, pp. 48-49)

- Vertical cooperation (along the supply chain) and horizontal (with competitors and entities from the sphere of science) in the area of implementation of new solutions (Oslo, 2005, p. 80)

With the independent variable technological parks were adopted, the services of which were not used by manufacturing companies in the studied provinces:

$$
X_{1 i}= \begin{cases}1, & \text { if the company used the park services } \\ 0, & \text { if the company did not use the park services }\end{cases}
$$

In the second part of the study, it was checked how the establishment of cooperation with the technological park influences the distance from the closest competitor and the main supplier and recipient, and the relations with them. In this situation, the dependent variable is the technological parks. The independent variable was the distance from the competitor, recipient and supplier and the relations of companies with these entities. In all cases, there were adopted four types of contacts. For the competitor these were: lack of contacts, close (cooperation), rather hostile and "neighbourly", for the supplier: only necessary, close (cooperation), rather reluctant, "neighbourly", and for the recipient: lack of contacts, close (cooperation), rather reluctant, "neighbourly". As in previous cases, value 1 was assigned in the situation, when the given type of relation occurred, and 0 when it did not.

In a situation in which for the study the dichotomous variables are adopted, the statistical modelling takes place using the probability theory. The analysis and interpretation of the results takes place like in the classical method of regression. The ways of selecting the model and testing hypothe- 
ses have a similar scheme. The most important differences which occur are brought down to the fact that calculations are more complicated and timeconsuming, and the calculation of values and making the residue charts often does not bring anything new to the model (Stanisz, 2007, p. 217).

In case of the model, where the dependent variable achieves the value 0 or 1 , the expected value of the dependent variable may be interpreted as the conditional probability of the realisation of the given event with the determined values of the independent variable (Świadek, 2011, p. 102). The applied probit modelling allowed to assess the chance of different innovation behaviours depending on the accepted boundary conditions (Świadek \& Szopik-Depczyńska, 2011, p. 98).

Parameter estimation of models with dichotomous variables takes place using the method of maximum likelihood. According to this, the vector of parameters is sought, which guarantees the highest probability of obtaining values observed in the sample (Welfe 1998, p. 73). Determining the statistical significance of the estimated parameters takes place using the $t$ Student statistics, which is based on the asymptotic errors of standard assessments. The verification of the model was conducted basing on the chisquare statistics. For the estimation of the models the confidence intervals at the level of 0,95 were adopted.

The estimated models have the form of the linear function $y=a x+b$. The positive sign by the directional coefficient means that the probability of occurrence of the given innovation phenomena (e.g. incurring expenditures on the $R \& D$ activity) under the influence of technological parks is greater than in the group of companies, which did not cooperate with the parks.

Calculations of the models were made in the Statistica program. In order to improve the clarity of the presented results in the article only those models were presented which met the conditions of the statistical significance and its main measures, i.e., standard errors of assessments, value of the $t$ Student and chi-square statistics. For them, the probability of the occurrence of particular innovation phenomena was also determined.

\section{Characteristics of the Study Sample}

The study illustrating the influence of technological parks on the innovation activity was conducted for the years of 2010-2012 among 773 industrial companies of the Silesian province and for the years of 2009-2011 among 680 companies of the Pomeranian province. The activity profile of the studied companies is qualified to the section C PKD 2007 the Industrial Manufacturing. 
The selection of provinces adopted for testing was dictated by a different level of the development of the industrial system on which they can be found. In terms of expenditures on the innovation activity, the Silesian province in 2012 is in the $2^{\text {nd }}$ position, and the Pomeranian on the $10^{\text {th }}$ place in the country. Expenditures on the research and developmental activity are similar in both regions. The Silesia province was ranked the $3^{\text {rd }}$, and Pomerania the $4^{\text {th }}$ in Poland. However, it should be emphasized that Silesia has been on this position for many years, while Pomerania was promoted from the $8^{\text {th }}$ position in 2010. In terms of the granted patents, the Silesian province is in the $3^{\text {rd }}$ place, and the Pomeranian one in the $8^{\text {th }}$ place in the country (ex quo with the West Pomeranian province). Thanks to this selection of the spatial framework of the study, it will be possible to determine the divergence in the functioning of technological parks due to the level of the development of the studied province.

Table 1. Expenditures on the innovation, research and developmental activity and the obtained patents in the studied provinces in 2012

\begin{tabular}{|l|c|c|c|}
\hline Province & $\begin{array}{c}\text { Expenditures on } \\
\text { innovation activity } \\
\text { (in thous. zl) }\end{array}$ & $\begin{array}{c}\text { Gross domestic } \\
\text { expenditures on } \\
\text { R\&D } \\
\text { (in mln zl) }\end{array}$ & Patents granted \\
\hline Silesian & 2744440 & 1298,5 & 213 \\
\hline Pomeranian & 620046 & 1011,1 & 85 \\
\hline
\end{tabular}

Source: own research based on website of Statistical Office in Katowice and Gdańsk.

In the Silesian province, most of the studied comapnies (nearly half) are the micro companies (employing up to 9 employees) and small ones (from 10-49 employees). Together, they constitute $80 \%$ of all studied companies. The share of average companies (from 50 to 249 employees) was over $17 \%$, and the large ones (employing over 250 people) nearly $3 \%$. In the Pomeranian province, this structure differs slightly. Micro and small companies constitute nearly $73 \%$ of the test sample, opposite to Silesia, where there are more small entities. The share of average companies in the sample was over $23 \%$ and large ones over $4 \%$. 
Table 2. Structure of the studied companies in terms of size classes distinguished based on the level of employment in the studied provinces in 2012

\begin{tabular}{|l|c|c|c|c|}
\hline \multirow{2}{*}{ Company size } & \multicolumn{4}{|c|}{ Province } \\
\cline { 2 - 5 } & \multicolumn{2}{|c|}{ Silesian } & \multicolumn{2}{c|}{ Pomeranian } \\
\cline { 2 - 5 } & $\begin{array}{c}\text { Number of } \\
\text { companies }\end{array}$ & Percentage & $\begin{array}{c}\text { Number of com- } \\
\text { panies }\end{array}$ & Percentage \\
\hline Micro & 337 & $43,6 \%$ & 211 & $31,0 \%$ \\
\hline Small & 281 & $36,4 \%$ & 283 & $41,6 \%$ \\
\hline Medium-sized & 133 & $17,2 \%$ & 158 & $23,3 \%$ \\
\hline Large & 22 & $2,8 \%$ & 28 & $4,1 \%$ \\
\hline Sum & 773 & $100 \%$ & 680 & $100 \%$ \\
\hline
\end{tabular}

Source: own research based on conducted survey.

Due to the level of the applied manufacturing technique in both provinces, there is the largest amount of the entities, whose activity profile is based on traditional areas of industry. However, it should be emphasized that in Silesia they constitute $44 \%$, and in Pomeranian as much as $53 \%$ of the studied population. On average, the low technique is used in the manufacturing process in both studied regions by almost $29 \%$ of the tested companies. In the Silesian province, the medium-high technique is used in almost $1 / 4$ of the studied companies, and in the Pomeranian province in $1 / 8$. The high technique is used in Silesia by over $4 \%$, and in Pomeranian by over $6 \%$ of the studied entities.

Table 3. Structure of the studied companies in terms of the level of technical advancement in the studied provinces in 2012

\begin{tabular}{|l|c|c|c|c|}
\hline \multirow{2}{*}{$\begin{array}{c}\text { Level of technical } \\
\text { advancement }\end{array}$} & \multicolumn{3}{|c|}{ Silesian } & \multicolumn{2}{c|}{ Pomeranian } \\
\cline { 2 - 5 } & $\begin{array}{c}\text { Number of } \\
\text { companies }\end{array}$ & Percentage & $\begin{array}{c}\text { Number of } \\
\text { companies }\end{array}$ & Percentage \\
\hline Low & 341 & $44,1 \%$ & 361 & $53,1 \%$ \\
\hline Medium-Low & 220 & $28,5 \%$ & 196 & $28,8 \%$ \\
\hline Medium-High & 180 & $23,3 \%$ & 81 & $11,9 \%$ \\
\hline High & 32 & $4,1 \%$ & 42 & $6,2 \%$ \\
\hline Sum & 773 & $100 \%$ & 680 & $100 \%$ \\
\hline
\end{tabular}

Source: own research based on conducted survey. 


\section{The Influence of Technological Parks on the Innovation of Industrial Companies in the Silesian and Pomeranian Provinces}

Analysing the activity of technological parks in the Silesian province it is observed that they significantly influence the innovation potential of industrial companies of this region. Their influence is visible in all studied innovation attributes except for the implementation of new products to the market. Therefore, it can be assumed that in this province there is a system stimulation of the innovation activity in the industry by the technological parks.

Using the services offered by technological parks to the greatest degree increases the chances of companies for investments in new fixed assets. They amount to $89 \%$ and are 20 percentage points higher than in the group of companies, which did not cooperate with this support institution. The detailed analysis of these investments indicates that parks to a greater extent increase the probability of increasing machine park of companies, rather than the purchase (or lease) of new buildings, or premises. In the first case, this probability is $p_{I}=0,83$, and in the second $p_{I}=0,45$. In groups of entities not cooperating with technological parks, these probabilities are significantly smaller and are for the investment in new machines and technical devices $p_{2}=0,57$, and for new buildings $p_{2}=0,25$.

Technological parks significantly increase the chances of implementing new technological processes. A positive phenomenon is the fact that this mostly applies to the introduction of new manufacturing methods - probability of this phenomenon is $p_{I}=0,74$ and is $76 \%$ higher than in the opposite group. In case of investment in new production systems and the supporting probability values are similar and amount to, respectively, $p_{I}=0,43$ and $p_{I}=0,45$. In companies which do not use the services of technological parks, they are about half the size.

Thanks to activity of parks in companies, the expenditures for new computer software are more often increased. The chances for this investment are $p_{I}=0,77$ and are nearly half higher than in the opposite group. These disproportions are even greater in case of stimulation of the research and developmental activity by the parks. Although probability is the smallest from the main groups of attributes of innovation, because it amounts to $p_{I}=0,66$, however it more than doubles the chances of the occurrence of this phenomenon in the opposite group of companies.

In the Pomeranian province technological parks increase the chance of the occurrence of the innovation activity in seven out of ten analysed areas. Their impact, therefore, cannot be considered as systemic, but their contri- 
bution to the improvement of the competitive situation of the region is significant.

Thanks to the activity of parks it can certainly be concluded that in the studied region the industrial companies which cooperate with them will implement new methods of manufacturing. The probability of occurrence of this phenomenon is $p_{I}=0,99$, and is 19 percentage points higher than in the group of companies which do not use the park services. This mainly refers to the investments connected with the implementation of systems supporting the activity of companies, where the chances for their occurrence are $38 \%$ and are more than half greater than in the opposite group.

Thanks to the cooperation with technological parks being almost certain, also the occurrence of investments in new fixed assets can be assumed. The chances of the occurrence of this phenomenon are 93\%. In most cases they apply to the increase, or the changes in the machine park of the studied companies, because the probability of occurrence of this investment is $p_{1}=0,75$ and is almost $1 / 4$ greater than in the opposite group.

Technological parks increase the chances to introduce new products to the market. They are $78 \%$ and are, like in the case of changes within the machine park, about $1 / 4$ greater than in the opposite group. The chances to introduce new computer software into the company under the influence of the cooperation with parks are 10 percentage points lower than in the case of the introduction of new products. In the opposite group, the probability of the occurrence of this phenomenon is $30 \%$ smaller and is $p_{2}=0,48$.

In the Pomeranian province technological parks significantly increase the probability of conducting the R\&D works. Thanks to cooperation with them, it is shaped at the level of $p_{I}=0,69$, and in the opposite group at $p_{2}=0,35$. Thus, after establishing cooperation with the technological park this probability will almost double.

In the Silesian province, technological parks significantly increase the chances of the occurrence of cooperation in the area of new solutions. Probability of establishing cooperation under their influence is $p_{I}=0,79$, and is more than two times bigger than in the group of companies which do not use the park services.

To the greatest degree, technological parks stimulate the introduction of new products in cooperation with suppliers. These chances are $55 \%$, and they are more than two times bigger than in the opposite group. Thanks to that, a threefold increase of the chances to establish the innovation cooperation with competitors is also noted $\left(p_{1}=0,15\right.$ compared to $\left.p_{2}=0,05\right)$. 
Table 4. The impact of technological parks on the innovation activity of industrial companies in the Silesian and Pomeranian province in the years of 2010-2012

\begin{tabular}{|c|c|c|c|c|c|c|}
\hline \multirow{4}{*}{$\begin{array}{l}\text { Innovation } \\
\text { Attributes }\end{array}$} & \multicolumn{6}{|c|}{ Technological parks } \\
\hline & \multicolumn{3}{|c|}{ Silesian province } & \multicolumn{3}{|c|}{ Pomeranian province } \\
\hline & \multicolumn{2}{|c|}{$p_{I}$} & $p_{2}$ & \multicolumn{2}{|c|}{$p_{1}$} & $p_{2}$ \\
\hline & $\sigma$ & $t$ & $\chi^{2}$ & $\sigma$ & $t$ & $\chi^{2}$ \\
\hline \multirow{3}{*}{ Expenditure on R\&D } & \multicolumn{3}{|c|}{$\mathbf{0 , 9 8 x - 0 , 5 7}$} & \multicolumn{3}{|c|}{$0,89 \times-0,39$} \\
\hline & \multicolumn{2}{|c|}{$\mathbf{0 , 6 6}$} & $\mathbf{0 , 2 9}$ & $\mathbf{0}$, & & 0,35 \\
\hline & 0,19 & 5,02 & 26,32 & 0,17 & 5,32 & 29,63 \\
\hline \multirow{3}{*}{$\begin{array}{l}\text { Investment in the so far under } \\
\text { invested fixed assets includ- } \\
\text { ing: }\end{array}$} & \multicolumn{3}{|c|}{$0,74 x+0,5$} & \multicolumn{3}{|c|}{$0,64 x+0,81$} \\
\hline & \multicolumn{2}{|c|}{$\mathbf{0 , 8 9}$} & \multirow{2}{*}{$\frac{\mathbf{0 , 6 9}}{10,23}$} & $\mathbf{0}$, & & 0,79 \\
\hline & 0,25 & 2,97 & & 0,23 & 2,74 & 8,72 \\
\hline \multirow{3}{*}{ a) buildings, offices and land } & \multicolumn{3}{|c|}{$0,53 x-0,66$} & & & \\
\hline & \multicolumn{2}{|c|}{$\mathbf{0 , 4 5}$} & $\mathbf{0 , 2 5}$ & & & \\
\hline & 0,19 & 2,76 & 7,54 & & & \\
\hline \multirow{3}{*}{$\begin{array}{l}\text { b) machinery and technical } \\
\text { devices }\end{array}$} & \multicolumn{3}{|c|}{$\mathbf{0 , 7 8 x}-\mathbf{0 , 1 8}$} & \multicolumn{3}{|c|}{$\mathbf{0 , 3 8 x}+\mathbf{0 , 3}$} \\
\hline & $\mathbf{0 , 8}$ & & 0,57 & $\mathbf{0}$, & &, 61 \\
\hline & 0,22 & 3,51 & 13,65 & 0,17 & 2,19 & 4,96 \\
\hline & & $64 x+0$ & & & $5 x-0,0$ & \\
\hline Software & $\mathbf{0 , 7}$ & & 0,53 & $\mathbf{0}$, & &, 48 \\
\hline & 0,21 & 3,1 & 10,22 & 0,17 & 3,01 & 9,29 \\
\hline & & & & & $44 x+0$ & \\
\hline ducts & & & & $\mathbf{0}$, & &, 63 \\
\hline & & & & 0,18 & 2,46 & 6,33 \\
\hline Implementation of new tech- & & $67 x+0$ & & & $34 x+0$, & \\
\hline nological processes, includ- & $\mathbf{0 , 8}$ & & 0,65 & $\mathbf{0}$, & & 0,8 \\
\hline ing: & 0,23 & 2,92 & 9,44 & 0,4 & 3,38 & 21,35 \\
\hline & &, $87 x-0$ & & & & \\
\hline a) manufacturing methods & $\mathbf{0 , 7}$ & & 0,42 & & & \\
\hline & 0,2 & 4,26 & 19,48 & & & \\
\hline & & ,48x-0 & & & & \\
\hline b) production-related systems & $\mathbf{0 , 4}$ & & 0,25 & & & \\
\hline & 0,19 & 2,54 & 6,36 & & & \\
\hline & &, $72 x-0$ & & &, $4 x-0$ & \\
\hline c) support systems & $\mathbf{0 , 4}$ & & $\underline{0,2}$ & $\mathbf{0}$, & &, 24 \\
\hline & 0,19 & 3,76 & 13,91 & 0,16 & 2,44 & 5,88 \\
\hline
\end{tabular}

$p_{1}-$ the predicted probability of the occurrence of the given type of innovation activity in the group of companies cooperating with technological parks

$p_{2}$ - the predicted probability of the occurrence of the given type of innovation activity in the other group of companies, i.e., not cooperating with technological parks

$\sigma$ - asymptotic standard error of the parameter estimator of the independent variable, i.e., technological park

$t$ - value of the t-Student distribution of the estimator of the parameter of the independent variable, i.e., technological park

$\chi^{2}-$ value of chi-square test of the estimated model

Source: own research based on conducted survey.

Thanks to the activity of parks, it comes to the search for new solutions in cooperation with such subjects from science like universities, national research institutes and developmental units, as well as the PAS unit. The 
probability of establishing cooperation with these entities are not high, in case of universities they are $p_{I}=0,21$, of scientific units $p_{l}=0,15$ and PAS units $p_{I}=0,09$, however, significantly outweigh the chances of occurrence of these phenomena in the group of entities not using the park services. In the first case, they are 4 times, and in the second time more than 3 times, and in the third one 9 times greater in the opposite group.

Table 5. Influence of technological parks on the establishment of cooperation in the area of new solutions in the Silesian and Pomeranian province in the years of 2010-2012

\begin{tabular}{|c|c|c|c|c|c|c|}
\hline \multirow{4}{*}{ Cooperation } & \multicolumn{6}{|c|}{ Technological parks } \\
\hline & \multicolumn{3}{|c|}{ Silesian province } & \multicolumn{3}{|c|}{ Pomeranian province } \\
\hline & \multicolumn{2}{|c|}{$p_{1}$} & $p_{2}$ & \multicolumn{2}{|c|}{$p_{1}$} & $p_{2}$ \\
\hline & $\sigma$ & $t$ & $\chi^{2}$ & $\sigma$ & $t$ & $\chi^{2}$ \\
\hline \multirow{3}{*}{ Cooperation with suppliers } & \multicolumn{3}{|c|}{$0,76 x-0,63$} & & & \\
\hline & \multicolumn{2}{|c|}{\begin{tabular}{|l|l|}
$\mathbf{0 , 5 5}$ & \\
\end{tabular}} & \begin{tabular}{|l}
$\mathbf{0 , 2 6}$ \\
\end{tabular} & & & \\
\hline & 0,19 & 4,02 & 16,23 & & & \\
\hline \multirow{3}{*}{$\begin{array}{l}\text { Cooperation with competi- } \\
\text { tiors }\end{array}$} & \multicolumn{3}{|c|}{$0,57 x-1,61$} & & & \\
\hline & \multicolumn{2}{|c|}{$\mathbf{0 , 1 5}$} & $\mathbf{0 , 0 5}$ & & & \\
\hline & 0,24 & 2,4 & 5,3 & & & \\
\hline \multirow{3}{*}{$\begin{array}{l}\text { Cooperation with Polish } \\
\text { Academy of Sciences de- } \\
\text { partments }\end{array}$} & \multicolumn{3}{|c|}{$1,03 x-2,4$} & & & \\
\hline & \multicolumn{2}{|c|}{0,09} & $\mathbf{0 , 0 1}$ & & & \\
\hline & 0,3 & 3,41 & 9,97 & & & \\
\hline \multirow{3}{*}{ Cooperation with universities } & \multicolumn{3}{|c|}{$0,87 x-1,66$} & & & \\
\hline & \multicolumn{2}{|c|}{$\mathbf{0 , 2 1}$} & $\mathbf{0 , 0 5}$ & & & \\
\hline & 0,22 & 3,93 & 14,06 & & & \\
\hline \multirow{3}{*}{$\begin{array}{l}\text { Cooperation with national } \\
\text { R\&D centres }\end{array}$} & \multicolumn{3}{|c|}{$\mathbf{0 , 7 3 x - 1 , 7 7}$} & & & \\
\hline & $\mathbf{0 , 1}$ & &, 04 & & & \\
\hline & 0,24 & 3,03 & 8,27 & & & \\
\hline \multirow{3}{*}{$\begin{array}{l}\text { Cooperation with foreign } \\
\text { R\&D centres }\end{array}$} & & & & \multicolumn{3}{|c|}{$1,13 x-2,48$} \\
\hline & & & & & & 0,01 \\
\hline & & & & 0,28 & 4,05 & 15,44 \\
\hline \multicolumn{7}{|l|}{ Cooperation with clients } \\
\hline \multirow{3}{*}{$\begin{array}{l}\text { General innovation coopera- } \\
\text { tion }\end{array}$} & \multicolumn{3}{|c|}{$1,07 x-0,28$} & \multicolumn{3}{|c|}{$0,46 x-0,16$} \\
\hline & \multicolumn{2}{|c|}{$\mathbf{0 , 7 9}$} & 39 & & & 0,43 \\
\hline & 0,21 & 5,09 & 28,86 & 0,16 & 2,85 & 8,26 \\
\hline
\end{tabular}

Source: own research based on conducted survey.

In the Pomeranian province technological parks increase the chance to establish the innovation cooperation by nearly half. In the group of entities using the services, the probability to establish cooperation in order to implement new solutions is $p_{I}=0,62$, and in the group not cooperating with parks $p_{2}=0,48$. Unfortunately, after e detailed examination of particular 
types of cooperation, it turned out that conditions of the statistical significance are met only by the model estimated for the cooperation with foreign research institutes. Thanks to the activity of parks, the chances of establishing cooperation with them are $9 \%$ and are 9 times greater than in the group of companies not cooperating with them.

\section{The Effect of the Location of the Main Competitor, Recipient and Supplier and the Relation Among Them on the Cooperation of Industrial Companies with Technological Parks}

In case of the Silesian province the importance in the manufacturing process of the technological park as the provider is in the location of the competitor on the local and national market. In case of the close proximity of the competitor (local market) a significant decrease of the chances to establish cooperation with technological parks is observed. They are only $2 \%$ and are 4,5 times smaller than in the group of entities, which closest competitor is located outside the local market. The situation is opposite in case of having the competitor on the national market. In such a situation, the chances to use the services of the technological park increase. The probability is $p_{I}=0,12$ and is 3 times greater than in the group of entities, which competitor is found in the region or abroad.

In the Pomeranian province greater chances for the establishment of cooperation with technological parks appear in the case when the closest competitor is located in the country, and in the situation when the relations with them are rather hostile. In the first situation, the probability of establishing cooperation is $p_{I}=0,14$, and in the second $p_{l}=0,19$. In the opposite groups, in both cases it is equal $p_{2}=0,09$.

In the Silesian province the significance on the selection of the technological park as the provider is found in thee local, national and foreign location of the main supplier. It can be noticed that the further located the supplier, the greater the chances to establish cooperation with the technological park. Having a supplier on the local market makes the chances of the company to use the park services are smaller than in the case of companies whose recipient is located in the region of the country, or abroad, altogether. It is $p_{l}=0,02$ and is 4 times smaller than in the opposite group. Having the supplier on the national and foreign market has a stimulating effect on cooperation with technological parks. The chances for the occurrence of this phenomenon in case of the supplier located in the country are $p_{1}=0,09$ (in the opposite group they are 1,8 times smaller), and abroad $p_{I}=0,16$ (in 
the opposite group they are 3,2 times smaller). In the Silesian province there is also increased probability to cooperate with the parks in case of cooperation with the main supplier. It is $p_{l}=0,07$. In the opposite group it is 1,5 smaller.

Table 6. Influence of the location and relations with the closest competitor to establish cooperation by the industrial companies with technological parks in the Silesian and Pomeranian province in the years of 2010-2012

\begin{tabular}{|c|c|c|c|c|c|c|}
\hline \multirow{4}{*}{$\begin{array}{l}\text { Location of the } \\
\text { competitor }\end{array}$} & \multicolumn{6}{|c|}{ Technological parks } \\
\hline & \multicolumn{3}{|c|}{ Silesian province } & \multicolumn{3}{|c|}{ Pomeranian province } \\
\hline & \multicolumn{2}{|c|}{\begin{tabular}{l|l}
$p_{1}$ &
\end{tabular}} & $p_{2}$ & \multicolumn{2}{|c|}{\begin{tabular}{l|l}
$p_{1}$ & \\
\end{tabular}} & $p_{2}$ \\
\hline & $\sigma$ & $t$ & $\chi^{2}$ & $\sigma$ & $t$ & $\chi^{2}$ \\
\hline \multirow{3}{*}{ Local } & \multicolumn{3}{|c|}{$-0,71 x-1,35$} & & & \\
\hline & \multicolumn{2}{|c|}{\begin{tabular}{|l|l|}
0,02 &
\end{tabular}} & 0,09 & & & \\
\hline & 0,19 & $-3,84$ & 17,74 & & & \\
\hline \multicolumn{7}{|l|}{ Regional } \\
\hline \multirow{3}{*}{ National } & \multicolumn{3}{|c|}{$0,6 x-1,75$} & \multicolumn{3}{|c|}{$0,29 x-1,36$} \\
\hline & \multirow{2}{*}{\multicolumn{2}{|c|}{$\begin{array}{r}\mathbf{0 , 1 2} \\
015\end{array}$}} & 0,04 & & \multicolumn{2}{|c|}{\begin{tabular}{l|l} 
& $\mathbf{0 , 0 9}$ \\
\end{tabular}} \\
\hline & & 4,02 & 15,81 & 0,15 & 1,97 & 3,77 \\
\hline \multicolumn{7}{|l|}{ Abroad } \\
\hline \multicolumn{7}{|c|}{$\begin{array}{l}\text { Relations with the competi- } \\
\text { tor }\end{array}$} \\
\hline \multicolumn{7}{|c|}{ Lack of contact } \\
\hline \multicolumn{7}{|l|}{ Cooperation } \\
\hline \multirow{3}{*}{ Rather hostile } & & & & \multicolumn{3}{|c|}{$0,46 x-1,33$} \\
\hline & & & & \multicolumn{2}{|c|}{\begin{tabular}{l|l}
0,19 & \\
\end{tabular}} & \multirow{2}{*}{\begin{tabular}{|l|}
$\mathbf{0 , 0 9}$ \\
\end{tabular}} \\
\hline & & & & 0,2 & 2,29 & \\
\hline "Neighbourly" & & & & & & \\
\hline
\end{tabular}

Source: own research based on conducted survey.

In the Pomeranian province, the importance of establishing cooperation with parks is found in the relations only with the supplier. In case of maintaining only essential contacts with them, the chances for the occurrence of this phenomenon are 5\% and are 2,2 times smaller than in the group of subjects which keep close, "neighbourly" or reluctant relations with the supplier. Cooperation with suppliers increases the chances for searching new solutions in the parks by 2 times, because they amount to $p_{I}=0,12$, and in the opposite group $p_{2}=0,06$. 
Table 7. Influence of the location and relations with the closest supplier to establish cooperation by the industrial companies with technological parks in the Silesian and Pomeranian province in the years of 2010-2012

\begin{tabular}{|c|c|c|c|c|c|c|}
\hline \multirow{4}{*}{$\begin{array}{l}\text { Location of the } \\
\text { supplier }\end{array}$} & \multicolumn{6}{|c|}{ Technological parks } \\
\hline & \multicolumn{3}{|c|}{ Silesian province } & \multicolumn{3}{|c|}{ Pomeranian province } \\
\hline & \multicolumn{2}{|c|}{$p_{1}$} & $p_{2}$ & \multicolumn{2}{|c|}{\begin{tabular}{l|l}
$p_{1}$ &
\end{tabular}} & $p_{2}$ \\
\hline & $\sigma$ & $t$ & $\chi^{2}$ & $\sigma$ & $t$ & $\chi^{2}$ \\
\hline \multirow{3}{*}{ Local } & \multicolumn{3}{|c|}{$-0,63 x-1,43$} & & & \\
\hline & $\mathbf{0}$, & \multicolumn{2}{|c|}{\begin{tabular}{l|l} 
& $\mathbf{0 , 0 8}$ \\
\end{tabular}} & & & \\
\hline & 0,22 & $-2,9$ & 10,38 & & & \\
\hline \multicolumn{7}{|l|}{ Regional } \\
\hline \multirow{3}{*}{ National } & \multicolumn{3}{|c|}{$0,31 x-1,67$} & & & \\
\hline & \multicolumn{2}{|c|}{\begin{tabular}{l|l}
0,09 & \\
\end{tabular}} & 0,05 & & & \\
\hline & 0,15 & 2,16 & 4,64 & & & \\
\hline \multirow{3}{*}{ Abroad } & \multicolumn{3}{|c|}{$0,66 x-1,63$} & & & \\
\hline & \multicolumn{2}{|c|}{0,16} & $\mathbf{0 , 0 5}$ & & & \\
\hline & 0,2 & 3,3 & 10,03 & & & \\
\hline \multicolumn{7}{|c|}{ Relations with the supplier } \\
\hline \multirow{3}{*}{ Essential contacts } & & & & \multicolumn{3}{|c|}{$-0,39 x-1,21$} \\
\hline & & & & \multicolumn{2}{|c|}{0,05} & $\mathbf{0 , 1 1}$ \\
\hline & & & & 0,18 & $-2,12$ & 4,9 \\
\hline \multirow{3}{*}{ Cooperation } & \multicolumn{3}{|c|}{$\mathbf{0 , 1 8 x - 1 , 6 8}$} & \multicolumn{3}{|c|}{$\mathbf{0 , 3 4 x - 1 , 5 2}$} \\
\hline & \multirow{2}{*}{\multicolumn{2}{|c|}{\begin{tabular}{c|c|c}
\multicolumn{2}{|c|}{$\mathbf{0 , 0 7}$} & \\
009 & 109 \\
\end{tabular}}} & 0,05 & \multicolumn{2}{|c|}{$\mathbf{0 , 1 2}$} & 0,06 \\
\hline & & & 3,48 & 0,15 & 2,26 & 5,34 \\
\hline \multicolumn{7}{|l|}{ Rather reluctant } \\
\hline "Neighbourly" & & & & & & \\
\hline
\end{tabular}

Source: own research based on conducted survey.

In the Silesian province, the importance of establishing cooperation with technological parks lies in having the main recipient on the national market and keeping close, or neighbourly relations with him. The recipient located on the national market increases the probability of establishing cooperation with parks 2,5 times, comparing to companies whose recipient is located locally, regionally or abroad. These chances increase also 4 times when the relations with the recipient are close. Staying in "neighbourly" relations with recipients makes the probability of establishing cooperation with parks smaller, than in case of other types of relations altogether. It is $p_{1}=0,03$ and it is almost two times smaller than in the other group of entities.

In the Pomeranian province, the importance in the selection of technological parks is played only by the possession of the recipient in a close distance. The chances for the cooperation to occur are 7\%, and in this case are 1,7 times smaller than in the opposite group. 
Table 8. Influence of the location and relations with the closest recipient to establish cooperation by the industrial companies with technological parks in the Silesian and Pomeranian province in the years of 2010-2012

\begin{tabular}{|c|c|c|c|c|c|c|}
\hline \multirow{4}{*}{$\begin{array}{l}\text { Location of the } \\
\text { recipient }\end{array}$} & \multicolumn{6}{|c|}{ Technological parks } \\
\hline & \multicolumn{3}{|c|}{ Silesian province } & \multicolumn{3}{|c|}{ Pomeranian province } \\
\hline & \multicolumn{2}{|l|}{$p_{1}$} & $p_{2}$ & \multicolumn{2}{|c|}{$p_{1}$} & $p_{2}$ \\
\hline & $\sigma$ & $t$ & $\chi^{2}$ & $\sigma$ & $t$ & $\chi^{2}$ \\
\hline \multirow{3}{*}{ Local } & & & & \multicolumn{3}{|c|}{$-0,29 x-1,19$} \\
\hline & & & & \multicolumn{2}{|c|}{\begin{tabular}{|l|l}
$\mathbf{0 , 0 7}$ & \\
\end{tabular}} & 0,12 \\
\hline & & & & 0,14 & $-2,01$ & 4,2 \\
\hline \multicolumn{7}{|l|}{ Regional } \\
\hline \multirow{3}{*}{ National } & \multicolumn{3}{|c|}{$0,48 x-1,76$} & & & \\
\hline & \multicolumn{2}{|c|}{$\mathbf{0 , 1}$} & 0,04 & & & \\
\hline & 0,15 & 3,29 & 10,82 & & & \\
\hline \multicolumn{7}{|l|}{ Abroad } \\
\hline \multicolumn{7}{|l|}{$\begin{array}{l}\text { Relations with the } \\
\text { recipient }\end{array}$} \\
\hline \multicolumn{7}{|l|}{ Essential contacts } \\
\hline \multirow{3}{*}{ Cooperation } & \multicolumn{3}{|c|}{$0,43 x-1,86$} & & & \\
\hline & \multirow{2}{*}{\multicolumn{2}{|c|}{$\begin{array}{r}\mathbf{0 , 3} \\
0.17\end{array}$}} & $\mathbf{0 , 0 8}$ & & & \\
\hline & & & 6,62 & & & \\
\hline \multicolumn{7}{|l|}{ Rather reluctant } \\
\hline \multirow{3}{*}{ "Neighbourly" } & \multicolumn{3}{|c|}{$-0,5 x-1,46$} & & & \\
\hline & $\mathbf{0 , 0 3}$ & & $\mathbf{0 , 0 7}$ & & & \\
\hline & 0,2 & $-2,41$ & 6,78 & & & \\
\hline
\end{tabular}

Source: own research based on conducted survey.

\section{Conclusions}

The analysis of the impact of technological parks on the innovation activity in the industry in the regional grasp showed that they play an important role in the process of implementation of new solutions in the analysed companies.

Comparison of the developed region (the Silesian province) with the region characterised by the intermediate industrial system (the Pomeranian province) illustrated differences in their impact. In the Silesian province, parks support the innovation activity to a greater degree than in the Pomeranian province. Therefore, the evolution of impact of the effectiveness of technological parks in terms of the level of development of the region was approximated. Despite the differences in the development, what is satisfac- 
tory is the fact that parks increase the chances to conduct the research and developmental activity in both analysed regions and the implementation of new manufacturing methods in the Silesian province and new products in the Pomeranian province. For them, these are the most desirable manifestations of innovation. Particularly important is the R\&D activity, whose conduct predicts the creation of completely new solutions, and not copying innovations created abroad.

The evolution of the activity of parks is particularly visible in the stimulation of cooperation established in order to implement new solutions. In the studied regions the influence of parks on the innovation cooperation altogether is also observed. However, when examining the influence of these support institutions on the specific types of cooperation, only in case of the Silesian province we can talk about the occurring regularities in this area. This is due to the fact that the innovation cooperation is a type of cooperation, which takes place most often in highly developed countries. In Silesia, with the exception of cooperation with suppliers, the values of probabilities for particular types of cooperation are shaped at a very low level. This means that it is in the embryonic phase. However, it is satisfactory that in this region cooperation with competitors appeared, which may predict the natural development of clusters and cooperation with entities from the area of science, which indicates the first signs of knowledge transfer from science to economy and commercialisation of the results of research results. In the Pomeranian province only a small impact of parks on cooperation with foreign scientific entities is noticeable. It results from the fact that in the area of innovation cooperation appears the evolution characterised by the transfer from the complete lack of interest with this type of activity in the region with the intermediate industrial system to its first symptoms in one of the most developed provinces in Poland.

In case of analysis of the determinants which influence the decision about establishing cooperation with technological parks it is observed that the greatest consistency characterised the distances from and relations with the competitor, recipient and supplier of companies in the Silesian than the Pomeranian province. This results from the fact that for the first ones more models meeting the conditions of the statistical significance were estimated.

In general, it can be assumed that companies entering into crossregional network relations favour the selection of the technological park as the catalyst of the innovation processes. In the Silesian region this found its confirmation in the distance from the competitor, supplier and recipient, and in the Pomeranian region from the competitor and recipient. 
In the Silesian province, having a competitor and a supplier on the local market results in the reduction of chances for establishing cooperation with technological parks. The situation is opposite when the company has a competitor and a recipient on the national market, and the supplier on the national or foreign market. In the Pomeranian province, the situation is similar, however, fewer regularities were stated (i.e. statistically significant models). Clearly stimulating for the establishment of cooperation with parks is the possession of a competitor in the country, and destimulating of the recipient on the local market. Such force systems can be justified by the claim that the need to overcome the spatial barriers in the search of the supplier or recipient requires additional effort from companies. Some assistance in this process can be sought in the support of technological parks. Additionally, it can be emphasized that the interest in technological parks are shown by companies from the sector of at least medium-low technology. In the studied regions, with the increase of the level of technique used by companies their number is decreasing. A smaller number of potential competitors, suppliers and customers caused the companies to search them outside the region. For this reason, the relations between the vertical and horizontal relations outside the region and the interest in technological parks can be observed.

To establish cooperation with technological parks, the relations with the competitor, supplier and recipient are significant. However, due to the smaller number of regularities it is difficult to determine the general rule of the influence of relations on the cooperation with these institutions.

In the Silesian province, the cooperation with the supplier or the recipient results in the increase of chances for using the services of technological parks, while neighbourly relations make them decrease. In the Pomeranian province, necessary relations with the supplier make the chances for the cooperation with parks decrease, and the hostile relations with the competitor and cooperation with the supplier make them increase. At this stage of the studies, due to the small number of models, it is difficult to clearly interpret this state of affairs. It can be assumed that cooperation brings companies tangible benefits, so it is not surprising that cooperation along the supply chain encourages its further development and results in entering into agreements with technological parks. Following this line of reasoning, one could try to explain that in the Pomeranian province maintaining only essential contacts with the supplier is a manifestation of the lack of interest in cooperation, and thus results also in the lack of interest in cooperation with parks. In the same region, the fight with competition causes the search of new resources to build the advantage on the market and thus encourage to 
cooperation with the parks, which are the source of innovation in the region.

In the light of the above conclusions, it can be assumed that the research hypothesis was confirmed. Technological parks increase the chances to implement innovations in the studied regions. There are also visible divergences associated with different levels of development of provinces. In Silesia (developed region) parks to a greater extent stimulate the innovation activity than in the Pomerania (average developed region).

\section{References}

Adamska, J. \& Kotara, J. (2011). Kreowanie środowiska innowacyjnego w parkach technologicznych. Poznań, Gliwice: Polska Agencja Rozwoju Przedsiębiorczości.

BMWi (2012). Wissen teilen und Märkte gewinnen. Praxisleitfaden „Innovationsmanagement in Netzwerken “. Berlin: Bundesministerium für Wirtschaft und Technologie.

Audretsch, D. B., (1998). Agglomeration and the location of innovative activity, Oxford Review of Economic Policy, 14(2).

Balcerzak, A. P., (2009a). Efektywność systemu instytucjonalnego a potencjał gospodarki opartej na wiedzy, Ekonomista, 6.

Balcerzak, A. P. (2009b). Wpływ działalności regulacyjnej państwa w obszarze kreowania ładu konkurencyjnego na rozwój nowej gospodarki. In A. P. Balcerzak, M. Moszyński (Ed.), Aktywność regulacyjna państwa a potencjał rozwojowy gospodarki. Toruń: Polskie Towarzystwo Ekonomiczne Oddział w Toruniu.

Jimenez-Moreno, J. J., Martinez-Canas, R., Ruiz-Palomino, P. \& Saez-Martinez, F. J. (2013). The Role of Science and Technology Parks in the Generation of Firm Level Social Capital Through University-Firm Relations: An Empirical Study in Spain. In J.J.M. Ferreira, M. Raposo, R. Rutten \& A. Varga (Eds.) Cooperation, Clusters and Knowledge Transfer. Universities and Firms Towards Regional Competitiveness. Berlin: Springer-Verlag.

Kessler, P. R. (2014). Future of Since and Technology Parks. Retrieved form: https://www.hdrinc.com/sites/all/files/content/articles/article-files/3288-futureof-science-and-technology-parks.pdf (26.11.2014).

Matusiak, K. B. (2009). Parki technologiczne. In K. B. Matusiak (Ed.) Ośrodki innowacji i przedsiębiorczości w Polsce. Raport 2009. Łódź, Warszawa: Polska Agencja Rozwoju Przedsiębiorczości.

Matusiak, K. B. (2008). Wpływ parków technologicznych na rozwój ekonomiczno-społeczny. In K. B. Matusiak \& A. Bąkowski (Eds.) Wybrane aspekty funkcjonowania parków technologicznych w Polsce i na świecie. Warszawa: Polska Agencja Rozwoju Przedsiębiorczości. 
Matusiak, K. B. (2004). Parki technologiczne. In K. B. Matusiak (Ed.). Ośrodki innowacji i przedsiębiorczości w Polsce. Raport 2004. Łódź, Poznań: Instytut Ekonomii UŁ, Stowarzyszenie Organizatorów Ośrodków Innowacji i Przedsiębiorczości w Polsce.

Mażewska, M. \& Tórz, A. (2012). Parki technologiczne. In A. Bąkowski, M. Mażewska (Eds.). Ośrodki innowacji i przedsiębiorczości w Polsce. Raport 2012. Warszawa: Polska Agencja Rozwoju Przedsiębiorczości.

OECD/Eurostat (2005). Oslo Manual: Guidelines for Collecting and Interpreting Innovation Data, 3rd Edition, The Measurement of Scientific and Technological Activities. OECD Publishing. DOI: 10.1787/9789264013100-en.

Sarif, S. Mhd. \& Ismail, Y. (2006). Technology Parks, Knowledge Transfer and Innovation: the Case of Malaysia's Information and Communication Technology (ICT) Small and Medium Enterprises. International Journal of the Information Systems for Logistics and Management (IJISLM), 1(2).

Stanisz, A. (2007). Przystępny kurs statystyki. Tom2. Kraków: Statsoft.

Świadek, A. (2011). Regionalne systemy innowacji w Polsce. Warszawa: Difin.

Świadek, A. \& Szopik-Depczyńska, K. (2011). Koniunktura a aktywność innowacyjna systemów przemysłowych w regionach Polski - modelowanie probitowe. Barometr Regionalny, 3(25).

Welfe, A. (1998). Ekonometria. Warszawa: PWE.

Finansowe wspieranie inwestycji. Dz. U. z 2002 r., Nr 41, poz. 363, art. 2, p.15. 